\title{
The Effect of Woogakseungmatang Extract on NO Production in LPS- Stimulated RAW 264.7 Cells
}

\author{
Na Young Jo \\ Department of Acupuncture \& Moxibustion Medicine, Je-Cheon Hospital of Traditional Korean Medicine, Semyung University

\section{우각승마탕이 LPS로 유도된 RAW 264.7 세포에서 NO 생산에 미치는 영향}

\author{
조나영 ${ }^{(1)}$ \\ 세명대학교 제천한방병원 침구의학과
}

\begin{abstract}
Objectives : Woogakseungmatang is a prescription medication mainly used to treat facial paralysis in Korean medicine. The purpose of this study is to investigate the effects of Woogakseungmatang on anti-inflammation and anti-oxidation. Methods : Woogakseungmatang was extracted using hot water. Cytotoxicity was assessed using the 3-(4,5-dimethylthiazol2-yl)-2,5-diphenyltetrazolium bromide(MTT) method; nitric oxide(NO) production and Prostaglandin $\mathrm{E}_{2}\left(\mathrm{PGE}_{2}\right)$ production in RAW cells treated with Woogakseungmatang were investigated; and the cytokine changes associated with inflammation were examined. The antioxidant capacity of Woogakseungmatang was measured using the 1,1-diphenyl-2-picrylhydrazyl (DPPH) method. Results : RAW cells treated with Woogakseungmatang showed $90 \%$ cell viability at a $100-\mu \mathrm{g} / \mathrm{ml}$ concentration. NO production was decreased by $15 \%$ at a $100-\mu \mathrm{g} / \mathrm{ml}$ concentration. $\mathrm{PGE}_{2}$ production was decreased by $18 \%$ at a $100-\mu \mathrm{g} / \mathrm{ml}$ concentration. Interleukin $1 \beta$ (IL-1 $\beta$ ), interleukin 6(IL-6), and tumor necrosis factor- $\alpha$ (TNF- $\alpha$ ) were significantly reduced at $100 \mu \mathrm{g} / \mathrm{ml}$ compared with those in the control group. The DPPH free radical scavenging capability was more than $50 \%$ at $100 \mu \mathrm{g} / \mathrm{ml}$. Conclusions : Woogakseungmatang showed only a slight anti - inflammatory effect at $100 \mu \mathrm{g} / \mathrm{ml}$ and it was difficult to confirm the concentration-dependent anti-inflammatory effect. Therefore, this study means to confirm the potential anti-inflammatory effects of Woogakseungmatang. Based on this research, more systematic and diverse studies should be conducted.
\end{abstract}

Key words : Woogakseungmatang, Seogakseungmatang, Anti-inflammation, Antioxidant, Macrophage, Korean Medicine

\section{Introduction}

An inflammatory reaction is a defensive reaction against a harmful stimulus to the living body. It is a defense mechanism of a living body that localizes the influence of an external stimulus to the cells and tissues of the living body to restore and maintain a damaged region to normal ${ }^{1}$. However, if a defense mechanism is not performed smoothly in the human body and the inflammation reaction continues, it is a main factor in various inflammatory diseases, such as skin diseases,

Received August 27, 2018, Revised September 20, 2018, Accepted September 20, 2018

Corresponding author: Na Young Jo

Department of Acupuncture \& Moxibustion Medicine, Je-Cheon Hospital of Traditional Korean Medicine, Semyung University, Semyung-ro 66, sinwoul-dong, Jecheon 27136, Korea

Tel: +82-43-649-1825, Fax: +82-43-645-1382, E-mail: cswcny2@hanmail.net

This paper was supported by the Semyung University Research Grant of 2017.

(c) This is an open access article distributed under the terms of the Creative Commons Attribution Non-Commercial License (http://creativecommons.org/licenses/ by-nc/4.0) which permits unrestricted non-commercial use, distribution, and reproduction in any medium, provided the original work is properly cited. 


\section{KOREAN JOURNAL OF ACUPUNCTURE}

asthma, cancer, coronary artery disease, and rheumatoid arthritis $^{2)}$. Therefore, the fast and effective defense against and elimination of inflammatory substances are essential for the prevention and treatment of various inflammatory diseases.

Woogakseungmatang consists of the substitution of Seogak (Rhinocerotidae unicornis L.) for Woogak (Bubalus bubalis L.) among the constituents of Seogakseungmatang. Seogak is the horn of a rhinoceros that has been cut and dried; the rhinoceros is an endangered species, and rhinos are protected by the Convention on International Trade in Wildlife Species, so these horns have been replaced with those of water buffalo.

Woogak is used to treat headaches, high fever, and skin diseases in Korean medicine; Woogak has similar efficacy to Seogak. In a recent clinical study, the use of Woogak rather than Seogak was effective for fever and pediatric fever; however, when Woogak is used instead of Seogak, its capacity must be increased. Generally, 30 120 g should be added to the daily intake capacity and boiled in water. In clinical practice, it is common to prescribe Woogak instead of Seogak ${ }^{3)}$.

In Donguibogam, Seogakseungmatang is used medicinally when the muscles are paralyzed and painful. It can be applied to the forehead, chin, and cheeks to treat facial pain and the paralysis of facial muscles. Therefore, Seogakseungmatang mainly uses facial pain for the same idiopathic paralysis $^{4}$.

Facial paralysis is the most common disease of the brain; it is caused by paralysis of the muscles of the eyes and mouth, and the symptoms can make a patient appear crooked on one side. The causes of this disease include thoughtfulness, overwork, and cold exposure. Symptoms can include senile neuropathy, sensory depression, abnormal sensation in the trigeminal nerve, facial numbness, pain, auditory irritability, larynx, and tinnitus ${ }^{5}$. In the case of facial paralysis with severe pain, anti-inflammatory drugs are prescribed to reduce the inflammatory response ${ }^{6}$. In Korean medicine, Woogakseungmatang is specifically prescribed for painful facial paralysis; therefore, it is necessary to study the antiinflammatory effect of Woogakseungmatang.
Previous studies on Seogakseungmatang have been used in cases of trigeminal neuralgia ${ }^{6}$ and antithrombotic studies ${ }^{7}$. Studies on the anti-inflammatory effects of Woogakseungmatang are severely limited; we studied 3-(4,5-dimethylthiazol2-yl)-2,5-diphenyltetrazolium bromide (MTT), nitric oxide (NO), Prostaglandin $\mathrm{E}_{2}\left(\mathrm{PGE}_{2}\right)$, and cytokine to determine the anti-inflammatory and 1,1-diphenyl-2-picrylhydrazyl (DPPH) effects of Woogakseungmatang.

\section{Materials and Methods}

\section{Materials}

The medicinal materials used in the experiments were purchased from OmniHub (Kyeongbuk, Korea). The prescription's composition was in accordance with Donguibogam (Table 1). Five batches of the prescription were placed in $3 \mathrm{~L}$ of water and subjected to hot water extraction for four hours. The filtrate was first filtered and then poured through filter paper. The filtrate was concentrated under reduced pressure in a rotary vacuum evaporator, and the concentrated solution was lyophilized in a free dryer for seven days. After drying, 26.53 $\mathrm{g}$ of concentrated product was obtained (yield: $7.07 \%$ ). The obtained powder was stored at $-80^{\circ} \mathrm{C}$ in a cryogenic freezer and diluted to the required concentration according to the experiment.

Table 1. Compositions of Woogakseungmatang. Prescription was based on Donguibogam. $6 \mathrm{~g}$ of Rhinocerotis Cornu was replaced with $48 \mathrm{~g}$ of Buffle Cornu

\begin{tabular}{cc}
\hline Components herbs of Woogakseungmatang & Content \\
\hline Buffle Cornu & $48 \mathrm{~g}$ \\
Cimicifugae Rhizoma & $5 \mathrm{~g}$ \\
Sapshnikoviae Radix & $4 \mathrm{~g}$ \\
Osterici Radix & $4 \mathrm{~g}$ \\
Cnidii Rhizoma & $3 \mathrm{~g}$ \\
Aconiti Koreani Tuber & $3 \mathrm{~g}$ \\
Angelicae Dahuricae Radix & $3 \mathrm{~g}$ \\
Scutellariae Radix & $3 \mathrm{~g}$ \\
Glycyrrhizae Radix & $2 \mathrm{~g}$ \\
Total & $75 \mathrm{~g}$ \\
\hline
\end{tabular}




\section{Cell culture}

The RAW 264.7 cells used in the experiments were purchased from Korean Cell Line Bank. Separated cells were suspended in $20 \mathrm{ml}$ of Dulbecco's Modified Eagle's Medium(DMEM) containing 10\% fetal bovine serum (FBS) and $1 \%$ penicillin and cultured in a cell incubator $\left(37^{\circ} \mathrm{C}, 5 \% \mathrm{CO}_{2}\right)$. There were 10 or fewer subcultures. C ells were subjected to adaptation times for 24 hours before the samples were treated.

\section{Cytotoxicity}

Cells were plated at $1 \times 10^{4}$ cells/well in a 96-well plate and cultured for 24 hours. The extracts were treated at 10, $25,50,100$, and $200 \mu \mathrm{g} / \mathrm{ml}$ for $24 \mathrm{~h}$. After incubation, 20 $\mu 1$ of MTT $(5 \mathrm{mg} / \mathrm{ml})$ solution was added and incubated in a cell incubator $\left(37^{\circ} \mathrm{C}, 5 \% \mathrm{CO}_{2}\right)$ for 4 hours. The supernatant of the sample was removed, $100 \mu 1$ of dimethyl sulfoxide (DMSO) was added, and it was shaken for 30 minutes. After the reaction, the absorbance at $570 \mathrm{~nm}$ was measured using an ELISA reader and the cell survival rate of the control group was expressed as a percentage.

\section{NO production}

Ninety six well plates at $1 \times 10^{4}$ cells/well were cultured for 24 hours. After cultivation, the cells were replaced with fresh culture medium. The cells were treated with $1 \mu \mathrm{g} / \mathrm{ml}$ of LPS. The extracts were treated at 10, 25, 50 and $100 \mu \mathrm{g} /$ $\mathrm{ml}$. And cultured for 24 hours in a cell culture incubator. The supernatant of the sample and the Griess reagent were mixed in the same ratio. The mixed sample was shaken for 5 minutes. The absorbance was measured at $540 \mathrm{~nm}$, The NO concentration was determined using the standard curve of the $\mathrm{NaNO}_{2}$ standard, and the $\mathrm{NO}$ value for the control was expressed as a percentage.

\section{PGE2 production}

Cells were seeded at $1 \times 10^{5}$ cells/well in a 12 well plate and cultured for 24 hours. After cultivation, the cells were replaced with fresh culture medium. The cells were treated with $1 \mu \mathrm{g} / \mathrm{ml}$ of LPS. The extracts were treated at 10, 25,
50 and $100 \mu \mathrm{g} / \mathrm{ml}$. And cultured in a cell culture incubator for 24 hours. Thereafter, the supernatant that was obtained by centrifugation at 1,200 rpm for five minutes was measured with a PGE2 elisa kit (R\&D Systems, USA) according to the manufacturer's instructions. The measurement result was obtained by multiplying the automatically calculated value by the dilution factor with the four-parameter logistic curve fit.

\section{Inflammatory cytokines}

Cells were plated at $1 \times 10^{5}$ cells/well in a 12 -well plate and cultured for 24 hours. After cultivation, the cells were replaced with fresh culture medium The cells were treated with $1 \mu \mathrm{g} / \mathrm{ml}$ of LPS. And then cultured in a cell culture incubator for 24 hours. Then, centrifugation was carried out at $1,200 \mathrm{rpm}$ for five minutes. Interleukin $1 \beta$ (IL- $1 \beta$ ), interleukin 6 (IL-6), and tumor necrosis factor $\alpha(\mathrm{TNF}-\alpha)$ were measured by the supernatant using a mouse cytokine immunoassay kit (Koma, Korea) according to the manufacturer's instructions, and the measured results were automatically calculated using a five-parameter logistic curve.

\section{Antioxidative activity}

For an antioxidant activity test of DPPH free-radical scavenging activity, $250 \mu \mathrm{M}$ of DPPH was dissolved in ethanol. Woogakseungmatang extract was prepared at concentrations of $0,10,25,50$ and $100 \mu \mathrm{g} / \mathrm{ml}$, mixed with $100 \mu 1$ of DPPH solution. Absorbance was measured at 515 nm. Ascorbic acid (0, 10, 50, 100, 200, and $400 \mu \mathrm{g} / \mathrm{ml})$ prepared at the same concentration was used as a positive control. The scavenging activity rate was calculated on the basis of the results without Woogakseungmatang extract.

DPPH free radical scavenging activity $(\%)=$

$$
\frac{\text { AbsorbanceofControl }- \text { Experimental }}{\text { AbsorbanceofControl }} \times 100
$$

\section{Statistical analysis}

The experimental results were expressed as mean \pm standard deviation (mean $\pm \mathrm{SD}$ ). One-way ANOVA analysis was used for each comparison and to verify statistical 
significance $(* * p<0.01 ; * p<0.05)$.

\section{Results}

\section{Cytotoxicity}

The cell viability was $100 \pm 0.49,99.46 \pm 0.69,98.17 \pm 0.57$, $97.55 \pm 1.89,92.18 \pm 2.97,85.39 \pm 1.54$, and $76.11 \pm 2.81 \%$ in the control group and at 10, 25, 50, 100, 150 and $200 \mu \mathrm{g} / \mathrm{ml}$, respectively. Woogakseungmatang extract showed no cytotoxicity at the $10,25,50$, and $100 \mu \mathrm{g} / \mathrm{ml}$ concentrations, but decreased by about 15 and $24 \%$ at 150 and $200 \mu \mathrm{g} / \mathrm{ml}$ compared with the control; thus, the 10, 25, 50, and $100 \mu \mathrm{g} / \mathrm{ml}$ concentrations were selected in subsequent experiments (Fig. 1).

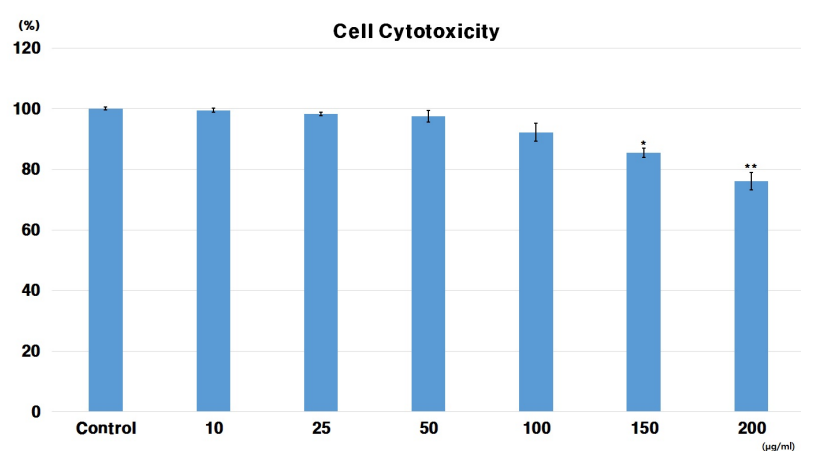

Fig. 1. This graph shows the cytotoxic effects of Woogakseungmatang extract in macrophage.

There is no significant cytoxicity up to $150 \mu \mathrm{g} / \mathrm{ml}$.

\section{NO production}

The means of NO treated with LPS alone is $31.40 \mu \mathrm{M}$. The NO production was $100.00 \pm 0.65,98.15 \pm 1.95,93.79 \pm 1.28$, $88.77 \pm 2.18$, and $85.13 \pm 1.93 \%$ in the control group and at $10,25,50$, and $100 \mu \mathrm{g} / \mathrm{ml}$, respectively. Woogakseungmatang extract showed approximately $85 \% \mathrm{NO}$ production at $100 \mu \mathrm{g} / \mathrm{ml}$ compared with the control; a significant difference was observed (Fig. 2).

\section{3. $\mathrm{PGE}_{2}$ production}

The means of $\mathrm{PGE}_{2}$ treated with LPS alone is $946.27 \mathrm{pg} / \mathrm{ml}$. The PGE2 production was $100 \pm 0.42,99.51 \pm 1.29$, $96.75 \pm 2.68,89.16 \pm 1.94$, and $82.64 \pm 2.54 \%$ in the control group and at 10, 25, 50, and $100 \mu \mathrm{g} / \mathrm{ml}$, respectively.

Woogakseungmatang extract showed a significant decrease in the amount of $\mathrm{PGE}_{2}$ produced at $100 \mu \mathrm{g} / \mathrm{ml}$ compared with the control (Fig. 2).

\section{Inflammatory cytokines}

Woogakseungmatang extracts were treated with cells, and their cytokine production was measured.

The means of IL- $1 \beta$ treated with LPS alone is 231.62 $\mathrm{pg} / \mathrm{ml}$. The IL- $\beta$ production was $100 \pm 0.79,98.54 \pm 1.28$, $96.41 \pm 3.97,91.25 \pm 2.19$, and $85.24 \pm 1.18 \%$ in the control group and at 10, 25, 50, and $100 \mu \mathrm{g} / \mathrm{ml}$, respectively.

The IL-1 $\beta$ production was reduced by approximately $9 \%$ at $100 \mu \mathrm{g} / \mathrm{ml}$ compared with the control. There was a
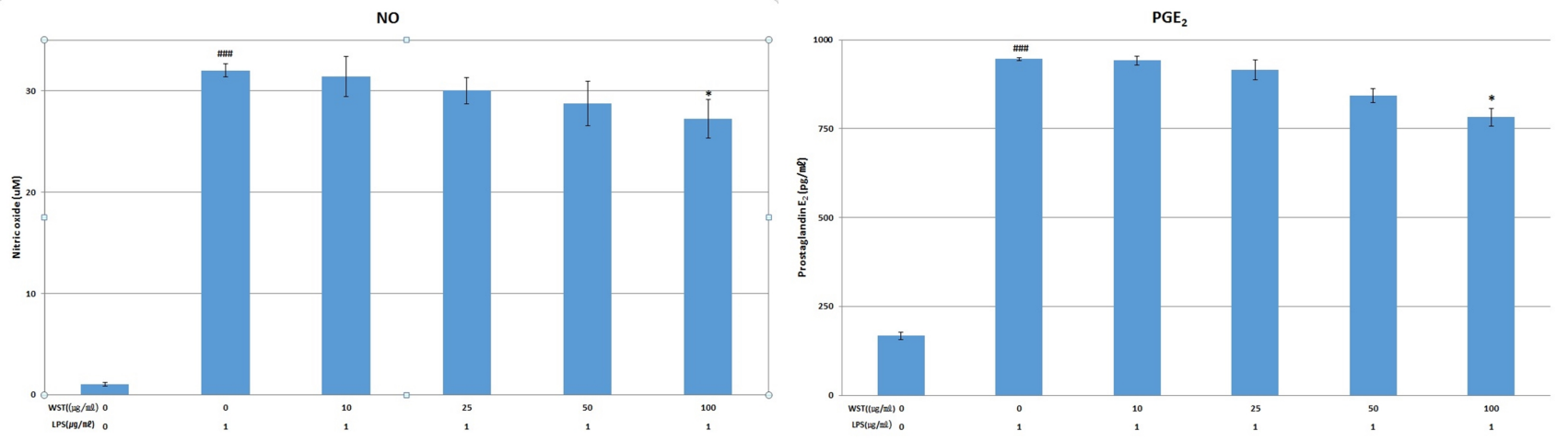

Fig. 2. LPS induced NO and PGE2 production. RAW 264.7 cells were preincubated with $10,25,50$ and $100 \mu \mathrm{g} / \mathrm{ml}$ of Woogakseungmatang. The cells were treated with $1 \mu \mathrm{g} / \mathrm{ml}$ of LPS to induce NO and PGE2 production. The NO production was measured by Griess Reagent System, and the PGE2 production was measured by ELISA as described in materials and methods. Data are represented as means \pm SEM.Significantly different from control (\#) or LPS alone $\left.{ }^{*}\right) ;{ }^{\# \# \#} p<0.001,{ }^{*} p<0.05$. 
significant decrease at $100 \mu \mathrm{g} / \mathrm{ml}$.

The means of IL-6 treated with LPS alone is $159.54 \mathrm{ng} / \mathrm{ml}$.

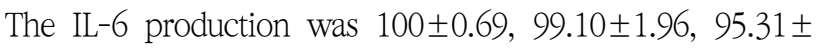
$2.84,92.74 \pm 1.48$, and $86.18 \pm 3.37 \%$ in the control group and at $10,25,50$, and $100 \mathrm{mg} / \mathrm{ml}$, respectively. Woogakseungmatang extract reduced IL-6 production by approximately 12 , 18 , and $20 \%$ at the $25-, 50-$, and $100-\mu \mathrm{g} / \mathrm{ml}$ concentrations, respectively. There was a significant decrease at $100 \mu \mathrm{g} / \mathrm{ml}$.

The means of TNF- $\alpha$ treated with LPS alone is 4395.59 $\mathrm{pg} / \mathrm{ml}$. The TNF- $\alpha$ production was $100 \pm 0.78,98.52 \pm 2.19$, $94.21 \pm 3.46,90.77 \pm 2.43$, and $84.20 \pm 3.94 \%$ in the control group and at 10, 25, 50, and $100 \mu \mathrm{g} / \mathrm{ml}$, respectively. The $\mathrm{TNF}-\alpha$ production was also reduced by approximately 19 and $25 \%$ at 50 and $100 \mu \mathrm{g} / \mathrm{ml}$, respectively. There was a significant decrease at $100 \mu \mathrm{g} / \mathrm{ml}$ (Fig. 3).

\section{Antioxidative activity}

The DPPH radical scavenging activity was $18.26 \pm 2.14$,
$23.87 \pm 2.96,35.11 \pm 3.73$, and 50.89 $\pm 3.59 \%$ compared with the control group at 10, 25, 50, and $100 \mu \mathrm{g} / \mathrm{ml}$, respectively. The DPPH radical scavenging activity of ascorbic acid and Woogakseungmatang extract was measured. The ascorbic acid-treated group showed more than $100 \%$ activity at 50 $\mu \mathrm{g} / \mathrm{ml}$. Woogakseungmatang extract significantly increased the DPPH radical scavenging ability in a concentrationdependent manner. The criteria for the data is that the reagents have not been processed. Woogakseungmatang extract at $100 \mu \mathrm{g} / \mathrm{ml}$ showed the highest DPPH radical scavenging ability (more than 50\%) (Fig. 3).

\section{Discussion}

Seogak is rhinoceros horn. In Korean medicine, it is said to have the effect of lowering fever, reducing edema, and eliminating side effects; however, rhinoceros is an
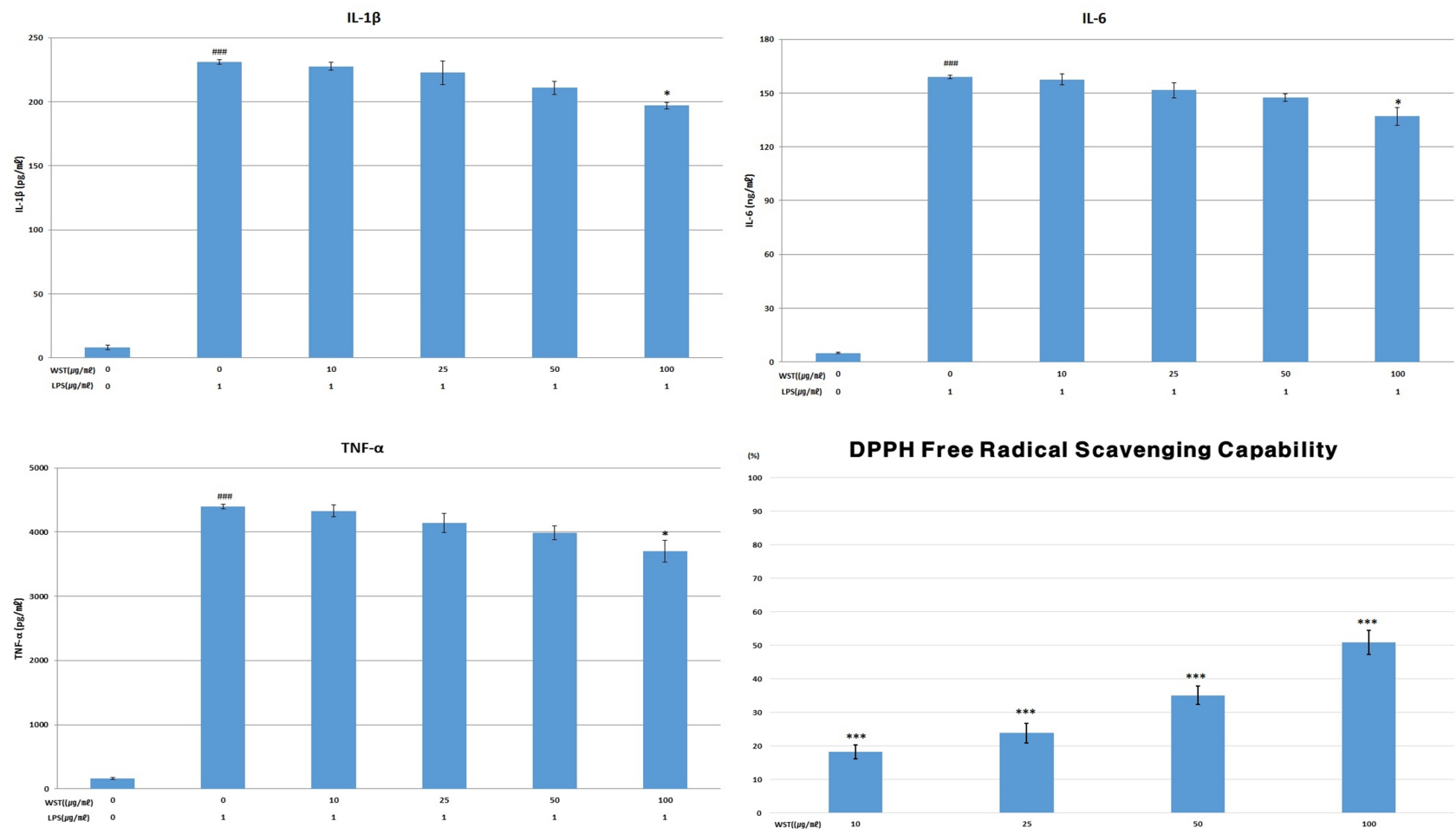

Fig. 3. Inhibition of LPS-induced IL-1 $\beta, \mathrm{IL}-6, \mathrm{TNF}-\alpha$ and DPPH radical by Woogakseungmatang extract.

RAW 264.7 cells were preincubated with $10,25,50$ and $100 \mu \mathrm{g} / \mathrm{ml}$ of Woogakseungmatang extract. The cells were treated with $1 \mu \mathrm{g} / \mathrm{ml}$ of LPS. The IL-1 $\beta$, IL-6 and TNF- $\alpha$ production was measured by ELISA as described in materials and methods. Data are represented as means \pm SEM.Significantly different from control (\#) or LPS alone $\left(^{\star}\right)$; ${ }^{\# \#, * \star \star} p<0.001,{ }^{\star} p<0.05$. 


\section{KOREAN JOURNAL OF ACUPUNCTURE}

internationally protected animal whose horns have limited use. Woogak has the same effect as Seogak because it has the effect of lowering and treating fever in Korean medicine. Seogak and Woogak have the same main components; therefore, Woogak is the most commonly used substitute for Seogak 3 .

Macrophages protect the body from foreign substances, viruses, microorganisms, etc. when they invade. They are robust and have a longer lifespan than neutrophils; in addition, they protect against the treatment of waste products and microorganisms that neutrophils cannot digest; they are also known to produce inflammatory cytokines and antitumor effects and have been used in this study.

As a result of the cytotoxicity test for Woogakseungmatang, approximately $15 \%$ of cells were killed at the $200-\mu \mathrm{g} / \mathrm{ml}$ concentration. Since this is a globally significant figure, the experiment proceeded to use $100 \mu \mathrm{g} / \mathrm{ml}$.

$\mathrm{NO}$ is an inflammatory factor and a major cause of various chronic inflammatory diseases. When inflammation occurs, macrophages are activated and produce NO. NO-activated leukocytes and macrophages help regenerate tissues after removing foreign matter; however, excess NO is known to cause cerebral infarction, degenerative neurological diseases, diabetes, and similar issues ${ }^{8}$. Thus, Woogakseungmatang extract showed the effect of reducing $\mathrm{NO}$ by approximately $15 \%$ at $100 \mu \mathrm{g} / \mathrm{ml}$ compared with the control, which is statistically significant.

The main symptoms of inflammation are pain, fever, redness, and swelling); $\mathrm{PGE}_{2}$ modulates these symptoms and increases the vascular permeability to spread leukocytes to inflammation sites. It is considered an inflammatory mediator, but induces IgE secretion depending on the target cell and promotes interleukin-4 (IL-4) and interleukin-5 (IL-5) production ${ }^{10}$. Woogakseungmatang extract showed the effect of reducing $\mathrm{PGE}_{2}$ significantly by approximately $18 \%$ at 100 $\mu \mathrm{g} / \mathrm{ml}$ compared with the control.

In general, the inflammatory response of macrophages activated by LPS involves inflammatory mediators, such as pro-inflammatory cytokines, NO, PGE 2 , LTB4, iNOS, and COX $-2^{11}$. Representative inflammatory cytokines involved in the development of inflammation are IL-1 $\beta$, IL-6, and TNF$\alpha$. Among these, IL-1 $\beta$ causes an inflammatory reaction, is involved in fever, and activates lymphocytes and neutrophils. IL-6 promotes the production of acute-phase protein (CRP) and develops chronic stages of inflammatory diseases, including allergic diseases. In addition, TNF-a activates leukocytes by causing an inflammatory reaction. However, excess cytokine causes thrombosis and tissue damage ${ }^{12}$. In this study, Woogakseungmatang extract significantly decreased IL-1 $\beta$ production at the $100-\mu \mathrm{g} / \mathrm{ml}$ concentration, IL-6 production was significantly decreased at 10 and $100 \mu \mathrm{g} / \mathrm{ml}$, and TNF- $\alpha$ was significantly reduced at $100 \mu \mathrm{g} / \mathrm{ml}$. These results show the potential of Woogakseungmatang extract to be used to prevent and treat various inflammatory diseases through the effective reduction of inflammatory cytokines ${ }^{13)}$.

Studies on the relationship between the cause of disease and oxidative byproducts by reactive oxygen species are underway $^{14)}$. Active oxygen is known to be harmful to proteins, biological membranes, and DNA. Therefore, studies on antioxidants have been actively conducted recently ${ }^{15}$. The DPPH free radical scavenging capability showed a tendency to increase in a concentration-dependent manner after Woogakseungmatang extract treatment. At the concentration of $100 \mu \mathrm{g} / \mathrm{ml}$, it showed more than 50\% scavenging ability.

Woogakseungmatang extract inhibits the inflammatory process by significantly reducing cytokine IL- 6 and TNF-a production. Woogakseungmatang extracts should be studied clinically and experimentally.

\section{Conclusion}

This paper investigates the anti-inflammatory effect of Woogakseungmatang extract using RAW 264.7 cells to measure the amounts of MTT, NO, and $\mathrm{PGE}_{2}$ and cytokines $\mathrm{IL}-1 \beta$, IL- 6 , and TNF- $\alpha$. Thus, the following conclusions were obtained:

1. There was no significant change in cell survival up to $100 \mu \mathrm{g} / \mathrm{ml}$ for Woogakseungmatang extract; cell viability was $76 \%$ at $200 \mu \mathrm{g} / \mathrm{ml}$. 
2. The amount of $\mathrm{NO}$ produced was significantly decreased by $85 \%$ at $100 \mu \mathrm{g} / \mathrm{ml}$ compared with the control.

3. The amount of $\mathrm{PGE}_{2}$ produced was significantly reduced by $82 \%$ at $100 \mu \mathrm{g} / \mathrm{ml}$ compared with the control.

4. IL-1 $\beta$, IL-6, and TNF- $\alpha$ were significantly reduced at $100 \mu \mathrm{g} / \mathrm{ml}$ compared with the control group.

5. The DPPH free radical scavenging capability was more than $50 \%$ at $100 \mu \mathrm{g} / \mathrm{ml}$.

According to this study, the Woogakseungmatang showed only a slight anti-inflammatory effect at $100 \mu \mathrm{g} / \mathrm{ml}$ the highest concentration that does not show cytotoxicity. In addition, it was difficult to confirm the concentrationdependent anti-inflammatory effect of the Woogakseungmatang. Therefore, this study means to confirm the potential antiinflammatory effects of Woogakseungmatang. A variety of anti-inflammatory studies of Woogakseungmatang are needed.

\section{Acknowledgements}

This paper was supported by the Semyung University Research Grant of 2017.

\section{References}

1. Vinay Kumar, Abbas, ASTER, Fausto, Robbins \&Cotran pathologic basis of disease. 8th, Seoul: Bummoon education. 2011 : 223-41.

2. Cheon MS, Yoon TS, Choi GY, Kim SJ, Lee AY, Moon BC, et al. Comparative Study of Extracts from Rhubarb on Inflammatory Activity in RAW 264.7 Cells. Korean J. Medicinal Crop Sci. 2009; $17(2): 109-14$.

3. The Korea Society of Korean Herbal medicine textbook compilation committee. Herbal medicine. 2nd. Seoul: Younglimsa. $2007: 229-30$

4. Heo J. Donguibogam. 3rd. Seoul: Donguibogam Publishers. $2006: 1003-5$.
5. The Korea Society of acupuncture and moxibution textbook compilation committee. Acupuncture and moxibution textbook. 2nd. Paju: Hanmi medical Publishers. 2017 : 229-30

6. Cho GS, Kim JH, Chung SH, Shin GJ, Lee WC. The clinical observation on I case of patient with trigeminal neuralgia. The J. of internal Korean medicine. 2000 ; 21(3) : 505-10.

7. Lee SI, Lee BJ, Lee TJ. Comparative Experimental Study of Anti-Thrombosis Effect Comparing Cornu Bubali , Cornu Bos tauri , Cornu Rhinoceri. The Korean J. Herbology. 1988 ; 3(1) : $19-48$.

8. Kain V, Prabhu SD, Halade GV. Inflammation revisited: inflammation versus resolution of inflammation following myocardial infarction. Basic Res Cardiol. 2014 ; 109(6) : 444. https://doi.org/10.1007/s00395-014-0444-7

9. The Korea Society of Korean Pathology textbook compilation committee. Korean Pathology. Iljungsa. 2004 : 109-12.

10. Chapter of The Korea Society of Pathlogists. Summarize Pathology. 1st. Seoul : Jungmoongak. 2008 : 81

11. Alanazi AM, El-Azab AS, Al-Suwaidan IA, ElTahir KE, Asiri YA, Abdel-Aziz NI, et al. Structure-based design of phthalimide derivatives as potential cyclooxygenase-2 (COX-2) inhibitors: anti-inflammatory and analgesic activities. Eur J Med Chem. 2015 ; 92(6) : 115-23. https://doi.org/10.1016/j.ejmech.2014.12.039

12. Fischer R, Maier O. Interrelation of oxidative stress and inflammation in neurodegenerative disease: role of TNF. Oxid Med Cell Longev. 2015 ; 2015(1) : 1-18. https://doi.org/10.11 $55 / 2015 / 610813$

13. Schett G, Elewaut D, McInnes IB, Dayer JM, Neurath MF. How cytokine networks fuel inflammation: Toward a cytokinebased disease taxonomy. Nat Med. 2013 ; 19(7) : 822-4. https://doi.org/10.1038/nm.3260

14. Wiseman H. Dietary inflence on membrane function; importwnt in protection against oxdative damage and disease. 7th. London: Nutritional Biochemistry. 1996:2-6. https://doi.org/10.1016/0955-2863(95)00152-2

15. Chang $S$, Ostric A. National antioxidants from rosmary and sage. J. Food Sci. 1977 ; 42(1) : 1102-10. 


\section{국문초록}

목적 : 우각승마탕은 한의학에서 안면마비 등 안면부의 통증 및 마비를 동반하는 질환에 주로 사용하는 처방이다. 본 연구의 목적은 LPS로 염증 반응을 유도한 대식세포에서 우각승마탕의 항염증 및 항산화 효과를 알아 보는 것이다. 방법: 동의보감 처방에 기반한 우각승마탕을 열 수추출한 후 동결건조 하였다. MTT 방법을 이용하여 세포 독성을 평가하였고, 우각승마탕 추출물을 처리한 RAW 세포에서 NO 생산 및 $\mathrm{PGE}_{2}$ 생성량을 조사 하였다. 또한 염증과 관련된 사이토카인(IL-1 $\beta$, IL-6, and TNF- $\alpha$ )의 생성량 변화를 조사 하였다. 우각승마탕의 항산화 효능 은 DPPH 법으로 측정 하였다. 결과 : 우각승마탕 추출물을 처리 한 대식세포는 $100 \mu \mathrm{g} / \mathrm{ml}$ 농도에서 $92.18 \pm 2.97 \%$ 의 세포 생존율을 보였다. 150 과 $200 \mu \mathrm{g} / \mathrm{ml}$ 농도에서 세포생존율은 각각 $85.39 \pm 1.54$ and $76.11 \pm 2.81 \%$ 로 통계적으로 유의한 감소가 있었다. $100 \mu \mathrm{g} / \mathrm{ml}$ 농도에 서 $\mathrm{NO}$ 생성량은 $85.13 \pm 1.93 \%$ 였으며, 대조군과 비교하여 유의한 감소가 나타났다. $\mathrm{PGE}_{2}$ 생성량은 $100 \mu \mathrm{g} / \mathrm{ml}$ 농도에서 $82.64 \pm 2.54 \%$ 이었고, 통계적으로 유의한 감소가 있었다. IL- $\beta$, IL-6, TNF- $\alpha$ 는 $100 \mu \mathrm{g} / \mathrm{ml}$ 에서 각각 $85.24 \pm 1.18,86.18 \pm 3.37,84.20 \pm 3.94 \%$ 였으 며, 대조군과 비교하여 통계적으로 유의한 감소를 나타내었다. DPPH free radical 소거능은 $100 \mu \mathrm{g} / \mathrm{ml}$ 에서 $50.89 \pm 3.59 \%$ 를 나타내었다. 결론: 본 연구의 결과로 미루어 볼 때 우각승마탕은 세포독성을 보이지 않는 최고 농도인 $100 \mu \mathrm{g} / \mathrm{m}$ 에서 미약한 항염증 효과를 나타내었고 농도의존적 항염증 효과를 확인되지 않았다. 따라서 본 연구는 우각승마탕의 잠재적 항염증 효과를 확인하는 의미가 있었다. 이 연구를 바탕으 로 우각승마탕의 안전하고 효과적인 임상적 사용을 위하여 체계적이고 다양한 연구가 수행되어야 할 것이다.

키워드 : 우각승마탕, 서각승마탕, 항염, 항산화, 대식세포, 한의학 